It may be noted here that the use of a condenser and the solutions given above will add to the accuracy of the method in which the carbon dioxide is weighed instead of measured.

LABORAIORY OF BOOTH, GARRETT \& BLAIR,

Philadelphia.

\title{
A NEW SAFETY DISTILLATION TUBE FOR RAPID WORK IN NITROGEN DETERMINATIONS.
}

\author{
BY CXRIL G. Hopkins. \\ Received December 12, 1895 .
}

I doing a large amount of work with fodders and fertilizers, involving several hundred determinations of nitrogen (by the Kjeldahl method), I have observed that the distillation tube (generally known as "Kjeldahl's connecting bulb tube," but doubtless more properly as Reitmeir's distillation tube) is frequently a source of error, due to the fact that it allows fixed alkali to be carried over mechanically. Especially is this the case when the distillation is carried on rapidly, and also when the contents of the distillation flask has a tendency to "bump."

In doing rapid work I have always found it necessary to have the lower end of these tubes reground before they would allow the liquid condensed in the bulb to run back into the distillation flask. Even after this is properly done the lower end of the tube is still open, and when the liquid boils violently or " bumps," small particles of it are often thrown up through the tube into the bulb. Sometimes these particles of strongly alkaline liquid strike the curved tube within the bulb, flow out to the end, and are forced into the tube and over into the condenser by the rapid current of vapor. This action is easily observed when the contents of the distillation flask is highly colored; and I find that the occurrence is familiar to chemists who have had much to do with nitrogen determinations.

I have obtained good results, however, by having the end of the tube within the distillation flask properly ground, and then protected by a larger glass tube, fastened to the distillation tube just below the rubber stopper, by means of a short piece of rubber tubing, and having an opening on the side and a jet at the lower end. This modification gave such good satisfaction that it finally led me to make a new distillation tube in which 
not only the tube which passes into the distillation flask, but also the tube within the bulb has an opening on the side and a jet at the end.

The form of this distillation tube and its advantage

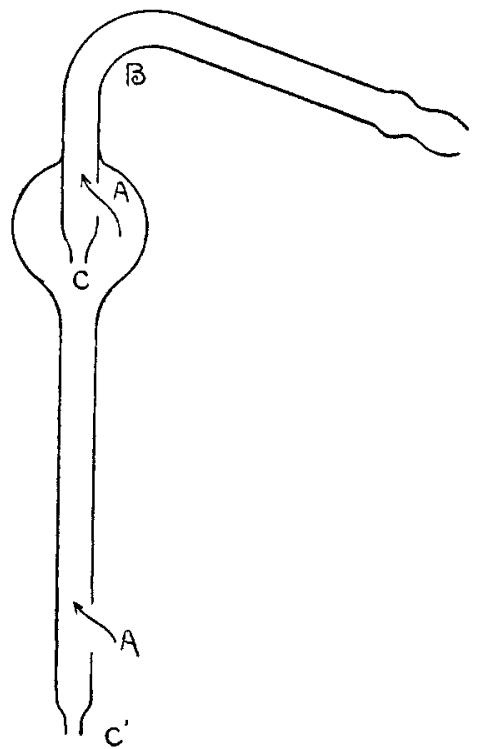

tube in ordinary use will be plainly seen in the accompanying illustration.

The vapor passes in through the side openings $A$ and $A^{\prime}$, and whatever condenses in the tube below the point $B$ passes back into the distillation flask through the jets $C$ and $C^{\prime}$.

The possibility of liquid from the distillation flask being thrown into the tube is avoided, and the current of vapor does not interfere with the return of condensed liquid. The jets $C$ and $C^{\prime}$ are two $\mathrm{mm}$. inside diameter and they always remain filled with returning liquid when in use. The tubing used in making these distillation tubes is from seven $\mathrm{mm}$. to eight $\mathrm{mm}$. inside diameter. The side openings $A$ and $A^{\prime}$ should be nearly as large, and the bulb about five $\mathrm{cm}$. in diameter. The length of the tube below the bulb is twelve $\mathrm{cm}$. and that above the bulb about the same.

UNIVERSTTY OF ILIINOIS, EXPERIMENT STATION.

\title{
REMARKS ON MR. AUCHY'S PAPER ON THE VOLUMETRIC DETERMINATION OF MANGANESE. ${ }^{\prime}$
}

\author{
BX GeORge C. STONE.
}

Receiverl January $I x$, I8966.

I $N$ the December number of the Journal of the American Chemical Society there is a paper by Mr. George Auchy on the "Volumetric Determination of Manganese," in which he advocates the use of Volhard's method, in which I heartily agree

1 Read before the New York Section. 